\title{
Identification of hydropedological flowpaths in Stevenson-Hamilton catena from soil morphological, chemical and hydraulic properties
}

\begin{tabular}{|c|c|}
\hline \multicolumn{2}{|c|}{$\begin{array}{l}\text { Authors: } \\
\text { Darren Bouwer }{ }^{1} \text { (]) } \\
\text { Pieter A.L. le Roux }{ }^{1} \\
\text { Johan van Tol }{ }^{1} \text { (I) }\end{array}$} \\
\hline \multicolumn{2}{|c|}{$\begin{array}{l}\text { Affiliations: } \\
{ }^{1} \text { Department of Soil, Crop } \\
\text { and Climate Sciences, Faculty } \\
\text { of Science and Agriculture, } \\
\text { University of the Free State, } \\
\text { Bloemfontein, South Africa }\end{array}$} \\
\hline \multicolumn{2}{|c|}{$\begin{array}{l}\text { Corresponding author: } \\
\text { Johan van Tol, } \\
\text { vantoljj@ufs.ac.za }\end{array}$} \\
\hline \multicolumn{2}{|c|}{$\begin{array}{l}\text { Dates: } \\
\text { Received: } 30 \text { Aug. } 2019 \\
\text { Accepted: } 05 \text { May } 2020 \\
\text { Published: } 29 \text { Oct. } 2020\end{array}$} \\
\hline \multicolumn{2}{|c|}{$\begin{array}{l}\text { How to cite this article: } \\
\text { Bouwer, D., Le Roux, P.A.L. \& } \\
\text { Van Tol, J., 2020, } \\
\text { 'Identification of } \\
\text { hydropedological flowpaths } \\
\text { in Stevenson-Hamilton } \\
\text { catena from soil } \\
\text { morphological, chemical and } \\
\text { hydraulic properties', Koedoe } \\
62(2) \text {, a1584. https://doi.org/ } \\
\text { 10.4102/koedoe.v62i2.1584 }\end{array}$} \\
\hline \multicolumn{2}{|c|}{$\begin{array}{l}\text { Copyright: } \\
\text { (C) 2020. The Authors } \\
\text { Licensee: AOSIS. This } \\
\text { is licensed under the } \\
\text { Creative Commons } \\
\text { Attribution License. }\end{array}$} \\
\hline \multicolumn{2}{|l|}{ Read online: } \\
\hline 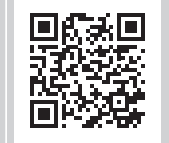 & $\begin{array}{l}\text { Scan this QR } \\
\text { code with your } \\
\text { smart phone or } \\
\text { mobile device } \\
\text { to read online. }\end{array}$ \\
\hline
\end{tabular}

In highly variable water regimes of semi-arid savannahs, water is the key driving force for biotic and abiotic processes. Understanding and measuring components of the hydrological cycle at landscape scale is however difficult because of the spatiotemporal variation of these processes. Hydropedology is a new interdisciplinary research field aiming to use soil information to conceptualise hydrological processes at different scales. In this study, a hydropedological approach was used to identify key hydrological flowpaths on a granitic catena in the Stevenson-Hamilton Supersite in the Kruger National Park. Soils from 49 plots, spaced $10 \mathrm{~m}$ apart along a catena, were classified, and their morphology was interpreted in relation to the dominant hydrological response. Soil samples were taken at 10-cm-depth intervals for chemical and physical analysis to assess the relationship between their expected hydrological behaviour and physiochemical properties. The hydropedological survey indicated that the crest is dominated by freely drained recharge soils where infiltration and vertical drainage are dominant. On the midslope, the underlying bedrock has restricted permeability; this promotes lateral flow at the soil/bedrock interface. On the upper footslope, high clay content soils (sodic) restricts further lateral drainage, resulting in return flow (seepage). Overland flow is dominant on the upper and lower footslope. The valley bottom is occupied by freely drained alluvial soils, which act as a recharge zone. The chemical and physical analyses of soil support the interpretations of the hydropedological interpretation of the soil morphology.

Conservation implications: Understanding hydrological processes is important for sustainable water resource management, especially in the areas with highly variable water regimes. A hydropedological approach provides an efficient method to characterise dominant flowpaths at landscape scale. This aids the estimation of the hydrological sensitivity of the landscape to climate and land use changes.

Keywords: Hillslope; Hydrology; Soil morphology; Semi-arid environments; Hydrological processes; Savanna ecosystems.

\section{Introduction}

Soil acts as a first-order control in the portioning of hydrological flowpaths and governing residence periods of water in a landscape. Water, on the other hand, is a primary agent in soil formation and leaves unique soil morphological signatures of water movement and storage. This interactive relationship between soil and water serves as the basis for a relatively new, interdisciplinary field of study called hydropedology (Lin 2010; Lin et al. 2006a). This synergistic research field promotes a more integrated approach to address complex issues regarding water resource management in variable water regimes of semi-arid landscapes (Kutílek \& Nielsen 2007; Lin 2003; Lin et al. 2006b). Hydropedological studies at landscape scale typically include various components of the hydrological cycle and recognise the intimate relationship between surface and groundwater at various spatiotemporal scales (Van Tol \& Lorentz 2018).

In the recent past, hydropedological studies done on landscape scale in South Africa have focussed on the interpretation of soil morphological properties, and their spatial distribution, in order to derive the hydrological behaviour of hillslopes and catchments (e.g. Van Tol et al. 2010; Kuenene et al. 2013). These qualitative descriptions of the dominant hydrological behaviour were then used to construct conceptual flowpath models that were used in hydrological modelling (Van Zijl et al. 2016) to determine the migration paths of pollutants (Mamera \& Van Tol 2018), wetland rehabilitation (Riddell, Lorentz \& Kotze 2012) and the impact of land-use changes (e.g. open-cast mining) on water resources (Van Tol et al. 2018). The underlying assumption of these hydrological interpretations of soil morphology is that soil morphological properties are reflecting the current soil-water regime.

Note: Special Issue: Connections between abiotic and biotic components of a granite catena ecosystem in Kruger National Park, sub-edited by Beanelri Janecke and Johan van Tol. 
The irreversible nature and slow reaction of some soil properties to soil-forming processes (especially climate) and the lack of morphological expression in immature soils question the correctness of interpretations derived from morphological properties alone (Lin et al. 2005). The process of soil formation is relatively long $\left(10^{2}-10^{4}\right.$ years), and soil morphology might, therefore, represent relict environmental conditions (MacEwan \& Fitzpatrick 1996). Although there is sufficient evidence that soil morphology correlates well to current soil water regimes in wetter parts of South Africa (e.g. Van Huyssteen et al. 2007; Van Tol et al. 2010), there is still a need to establish these correlations in drier climates.

Soil chemical properties are less buffered to environmental changes than morphological properties (MacEwan 1997). The factors influencing chemical processes are similar to those influencing pedological process (Kutílek \& Nielsen 2007), water being the prime mediator of chemical reactions in soils (Essington 2004). Soil chemical properties and their spatial distribution (vertically and laterally) can, therefore, be interpreted to identify hydrological flowpaths (Bouwer et al. 2015) and verify the correctness of interpretations and conceptual models of hydrological behaviour that were derived from soil morphology alone.
This work forms part of a larger interdisciplinary project that focused on the aboveground-belowground ecological patterns and their relationship with granitic catenal processes in the Kruger National Park (KNP). In most arid and semi-arid areas, water is the primary driver of ecological patterns and processes. In this article, we aimed to characterise the dominant hydropedological response of the granite catena using different levels of soil information. The objective was firstly to use soil morphological properties and relate them with soil-forming processes to deduct the dominant hydrological processes in different soils along the catena. Secondly, soil chemical properties and their spatial distribution were interpreted to verify whether the morphological properties in this catena are in sync with the current climate. The last objective was to measure selected hydraulic properties to quantify dominant flow processes and mechanisms.

\section{Methods}

\section{Study area}

The site is a granite catena of third-order stream in the Southern Granite supersite (Smit et al. 2013) in the Kruger National Park, South Africa (Figure 1). The mean annual precipitation is $560 \mathrm{~mm} / \mathrm{a}$ (Smit et al. 2013) and the geology

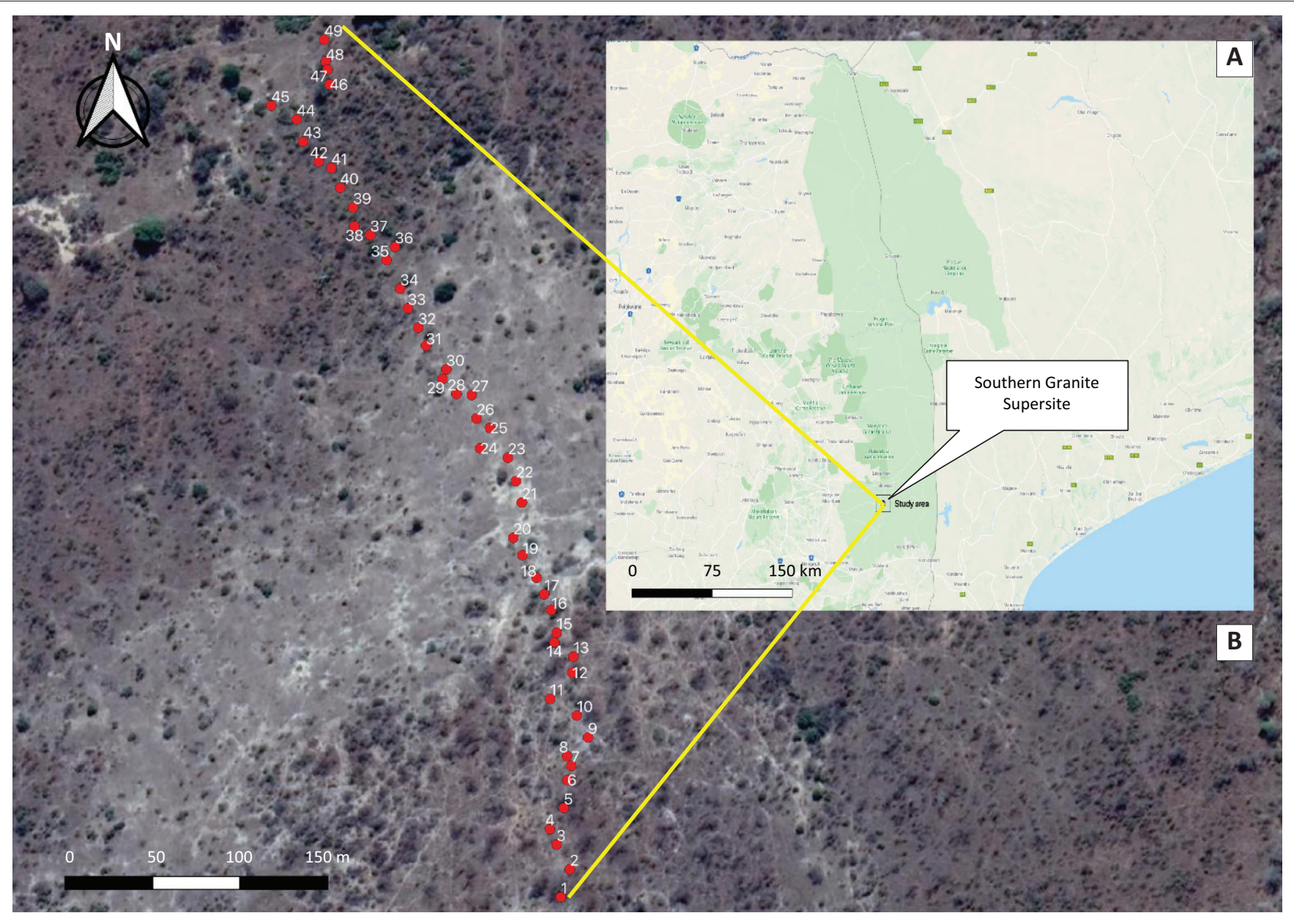

Source: Google Earth Pro v 7.3.2.5791, Maxar Technologies, 2020

FIGURE 1: (a) Location of the Southern Granite Supersite in the Kruger National Park in South Africa and (b) location of soil observations on the identified catena. 
comprises granites and gneissic migmatites of the Nelspruit suite (Dippenaar \& Van Rooy 2014; Robb et al. 2006).

The crest to the midslope is associated with gentle gradients and comprises apedal soils frequented by Terminalia sericea (Riddell et al. 2014). In the lower midslope positions, there is an abrupt transition to sodic duplex soils. Woody vegetation dominates the crest (Combretum apiculatum and Combretum zeyheri), whilst Acacia nilotica dominates the lower slopes and Euclea divinorium is associated with the duplex sodic soils (Smit et al. 2013).

\section{Data collection}

As part of a greater study, botanists laid out 49 plots of $10 \mathrm{~m}^{2}$ from the crest of the hillslope to the valley bottom at $10-\mathrm{m}$ intervals. Soil observations were made to refusal using a hand auger in the centre of these plots, effectively creating a 10-m-interval transect. The soils were classified according to the Soil Classification Working Group (SCWG 1991) and the International Union of Soil Sciences Working Group World Reference Base (WRB 2015). The soil properties and their spatial distribution were interpreted and related to their hydropedological significance and reclassified into hydrological soil types (Van Tol \& Le Roux 2019).

Soil samples were collected from the top and subsoil horizons of 49 observations. Four modal profiles were identified based on terrain position and soil type. These modal profiles were located on the crest, upper footslope, lower footslope and valley bottom terrain positions (Figure 2). These profiles were sampled at $100 \mathrm{mmdepth}$ intervals.

\section{Analysis}

The samples were dried, sieved and analysed according to standard methods (The Non-Affiliated Soil Analysis Work Committee 1990). Samples were analysed for particle distribution using the pipette method and $\mathrm{pH}\left(\mathrm{H}_{2} \mathrm{O}\right.$ and $\left.\mathrm{KCl}\right)$ with 1:2.5 solution. The soluble and exchangeable cations and cation exchange capacity were determined using $\mathrm{NH}_{4} \mathrm{OAc}$ solution.

Selected laboratory analyses were presented as average values of the entire profiles for 49 observations as well as the vertical distribution of selected elements for the modal profiles. The $S$-value was used to express the total content of basic cations (expressed as equivalent values):

$S-$ value $=\Sigma(\mathrm{Na}, \mathrm{Ca}, \mathrm{Mg}, K)$

[Eqn. 1]

and the exchangeable sodium percentage (ESP) was calculated as follows:

$\mathrm{ESP}=\frac{N a}{S-\text { value }} \times 100$

[Eqn. 2]

Soil hydraulic properties were determined on three profiles representing diagnostic horizons dominating the upslope, midslope and valley bottom positions. The saturated hydraulic conductivity of each diagnostic horizon in the

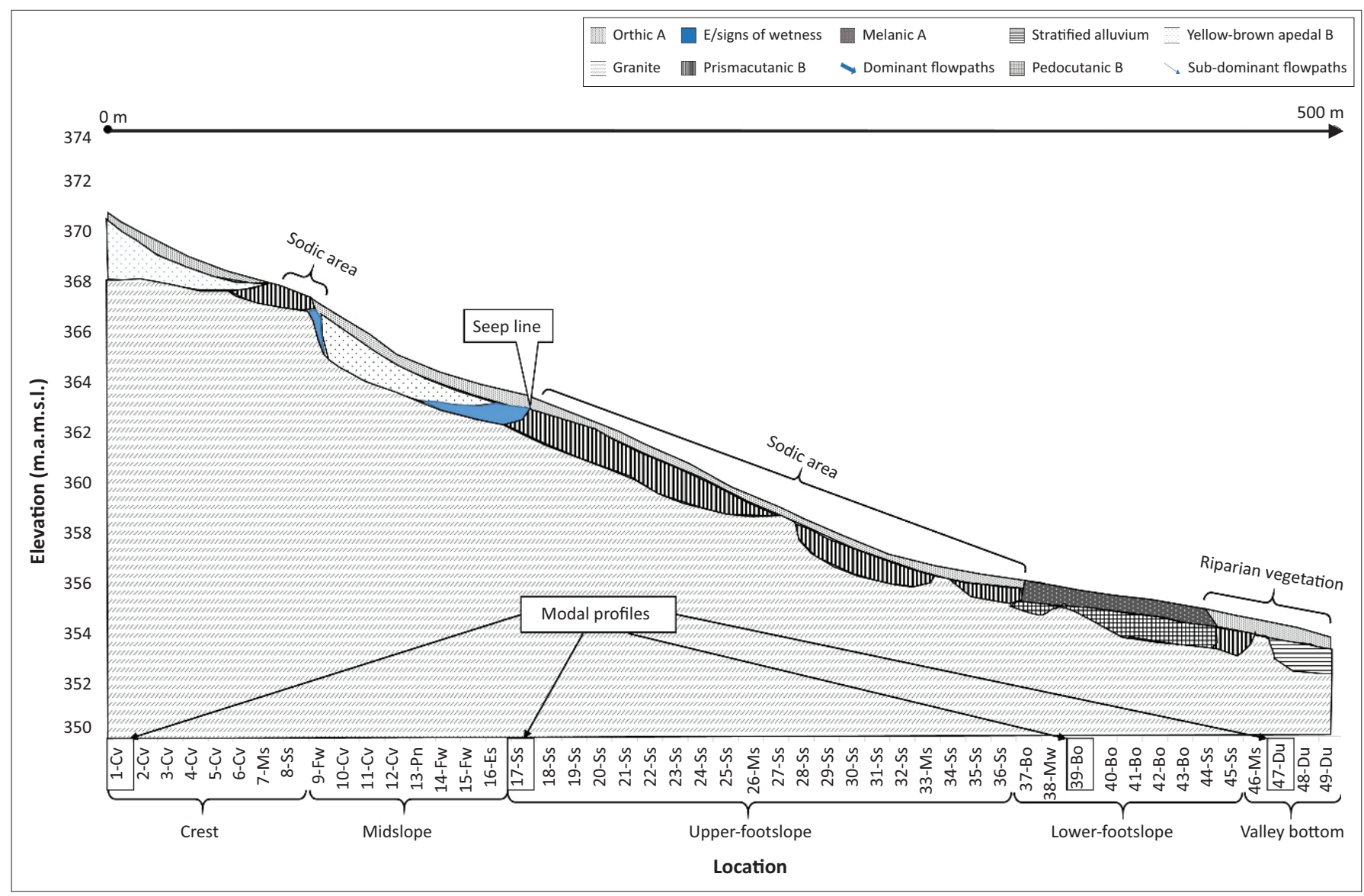

Cv, Clovelly; Ms, Mispah; Ss, Sterkspruit; Fw, Fernwoord; Pn, Pinedene; Es, Estcourt; Bo, Bonheim; Mw, Milkwood; Du, Dundee.

FIGURE 2: Soil distribution pattern and location of observations, soil types and modal profiles. 
modal profiles was measured in duplicate using the modified Bouwer and Rice (1976) double-ring falling-head method:

$K_{\mathrm{S}}=\frac{L}{t} \times \ln \left(\frac{\left(h_{0}+L\right)}{\left(h_{1}+L\right)}\right)$

where $K_{\mathrm{s}}$ is the saturated hydraulic conductivity $\left(\mathrm{mm} \mathrm{h}^{-1}\right), L$ is the thickness of the horizon, $t$ is the time until constant infiltration and $h_{0}$ and $h_{1}$ are the heads of water above the surface before and after $t$ respectively.

Water retention characteristics were measured for each horizon of the modal profiles on undisturbed core samples. The samples were de-aired at $-70 \mathrm{kPa}$ at room temperature for $24 \mathrm{~h}$. Water was then allowed to gradually flow out of the chambers. The saturated samples were mounted on a hanging water column setup in accordance with the procedure shown by Dirksen (1999). The suction levels $(h)$ were set at $0 \mathrm{~mm}, 38 \mathrm{~mm}$, $50 \mathrm{~mm}, 100 \mathrm{~mm}, 200 \mathrm{~mm}, 400 \mathrm{~mm}, 600 \mathrm{~mm}$ and $800 \mathrm{~mm}$. The gravimetric water content was determined at each level. The samples were then oven-dried at $105{ }^{\circ} \mathrm{C}$ to determine the bulk density to calculate the volumetric water content $\left(\theta_{\mathrm{v}}\right)$.

\section{Ethical considerations}

Ethical approval to conduct the study was obtained from the Interfaculty Animal Ethics Committee of the University of the Free State (reference No. UFS-AED2019/0121).

\section{Results}

\section{Soil classification and morphology}

The soil types range from sandy and apedal soils on the crest to strongly structured soils on the footslope with alluvial deposits on the banks on the river (Figure 2). The soil forms and their associated hydropedological grouping are presented in Table 1. Clovelly soils dominate the crest position. There is a small sodic area, covered by Sterkspuit soils on the transition from the crest to the midslope position. Fernwood and Pinedene (Arenosols) soil forms are found on the midslope. These soils are relatively deep $(>750 \mathrm{~mm}$ ) when compared to the soils on the footslope. The upper part of the footslope is dominated by the Sterkspruit (Solonetz) soils. The change in soil type (from sandy to clayey duplex) is correlated with a change in vegetation, that is, from woody vegetation to small shrubs. Topsoil horizons of these duplex soils are shallow and often eroded completely (Table 1). The lower footslope position is characterised by the pedocutanic horizons of the Bonheim (Luvisol) having a strongly developed blocky structure. The textural discontinuity is, however, not as dominant in these soils as in the Sterkspruit soils. Dundee soil (Fluvisol) is found along the streambeds (valley bottom). These soils are characterised by alluvial layering.

\section{Soil chemistry and physical properties}

\section{Catenal distribution of soil properties}

Profile average particle size distribution and chemical trends along the catena are presented in Figure 3. Drastic differences in clay and silt+clay percentages are observed between apedal horizons and the sodic zones (prismacutanic horizons; Figure $3 b)$. The upper- and lower-footslope positions are marked by relatively high silt+clay contents $(>30 \%)$. In the alluvial soils of the valley bottom, there is a marked decrease in the clay contents. The highest average clay content (30\%) was recorded in the Milkwood soil form (plot 38; Figure 2) and the lowest (1.2\%) in the Mispah soil form of plot 7 (Figure 2). The average contents of basic cations follow the same trends as the clay and

TABLE 1: Soil forms, diagnostic horizons, world reference base groups and hydropedological response types on the catena.

\begin{tabular}{|c|c|c|c|c|}
\hline \multicolumn{3}{|c|}{ South African soil taxonomy } & \multirow{2}{*}{$\begin{array}{l}\text { World Reference Base } \\
\text { Reference soil group }\end{array}$} & \multirow[t]{2}{*}{ Hydropedological soil type } \\
\hline Soil form & Master horizon with average thickness (mm) & Diagnostic horizon & & \\
\hline \multirow[t]{3}{*}{ Clovelly (Cv) } & $A(250)$ & Orthic & Arenosol & Recharge (deep) \\
\hline & $B(350)$ & Yellow-brown apedal & & \\
\hline & $C(200)$ & Saprolite & & \\
\hline \multirow[t]{3}{*}{ Pinedene (Pn) } & $A(200)$ & Orthic & Arenosol & Interflow (soil/bedrock) \\
\hline & B (200) & Yellow-brown apedal & & \\
\hline & $C(400)$ & Unspecified with signs of wetness & & \\
\hline \multirow[t]{2}{*}{ Fernwood (Fw) } & $A(200)$ & Orthic & Arenosol & Interflow (soil/bedrock) \\
\hline & $E(300)$ & E Horizon & & \\
\hline \multirow[t]{3}{*}{ Estcourt (Es) } & $A(100)$ & Orthic & Lixisol & Interflow (A/B) \\
\hline & $E(200)$ & E Horizon & & \\
\hline & $B(200)$ & Prismacutanic & & \\
\hline \multirow[t]{2}{*}{ Sterkspruit (Ss) } & $A(100)$ & Orthic & Solonetz & Responsive (shallow) \\
\hline & $B(300)$ & Prismacutanic & & \\
\hline \multirow[t]{2}{*}{ Bonheim (Bo) } & A (200) & Melanic & Luvisol & Recharge (deep) \\
\hline & $B(500)$ & Pedocutanic & & \\
\hline \multirow[t]{2}{*}{ Mispah (Ms) } & $A(200)$ & Orthic & Leptosol & Responsive (shallow) \\
\hline & $\mathrm{R}$ & Rock & & \\
\hline \multirow[t]{2}{*}{ Milkwood (Mw) } & $A(300)$ & Melanic & Leptosol & Responsive (shallow) \\
\hline & $\mathrm{R}$ & Rock & & \\
\hline \multirow[t]{2}{*}{ Dundee (Du) } & A (200) & Orthic & Fluvisol & Recharge (deep) \\
\hline & $B(750)$ & Stratified Alluvium & & \\
\hline
\end{tabular}


silt+clay contents (Figure 3c). When the impact of the clay content is neutralised, it is clear that $\mathrm{Na}$ is dominant in the sodic sites of the upper-footslope, whereas $\mathrm{Ca}$ is more prominent in the valley bottom (Figure $3 \mathrm{~d}$ - note the difference in scale between primary and secondary $y$-axis). Average $\mathrm{pH}$ values are below 6 in the crest and midslope positions (apedal horizons) but tend to increase downslope. Considerable fluctuation is observed in the $\mathrm{pH}$ values. The ESP is relatively low in the upper sections of the slope, increases above $6 \%$ (the threshold for classification of sodic soils) in the upper-footslope position and decreases notably below the sodic sites (Figure 3e).

\section{Vertical distribution of properties in modal profiles}

The Clovelly soil forms of the crest have a relatively uniform distribution of silt+clay with depth (Figure 4a). Bonheim soils show a typical increase in silt+clay up to a maximum value of $53 \%$ at $550 \mathrm{~mm}$ depth. The topsoil of this Sterkspruit soil was eroded, but the silt+clay contents were generally high $(>45 \%)$. Dundee soils develop from alluvial deposits and are therefore prone to textural variation, and this is reflected in Figure 4(a) in the distribution of silt+clay with depth.

The $\mathrm{pH}$ ranges from 5.1 in the subsoil of the Clovelly to 7.8 in the pedocutanic horizon of the Bonheim soil (Figure 4b). pH values of the surface horizons are similar for all soil forms in Figure 4(a). All profiles show an initial decline in $\mathrm{pH}$ with depth. This decline is more pronounced in the Clovelly soil. The initial decline is followed by an increase in $\mathrm{pH}$ of more than 1 and 2 units in the Sterkspruit and the Bonheim soils respectively. The Dundee soil again shows considerable variation because of the nature of alluvial deposits (Figure $4 b$ ).

The $S$-value ranges from $0.48 \mathrm{cmol}_{c} \cdot \mathrm{kg}^{-1}$ in the Clovelly soil to more than $37 \mathrm{cmol}_{\mathrm{c}} \cdot \mathrm{kg}^{-1}$ in the pedocutanic horizon of the Bonheim form (Figure 4c). The $S$-value is relatively constant throughout the Clovelly soil. The $S$-value decreases drastically from 50 to $150 \mathrm{~mm}$ in the Bo soil, from where it increases to the $550 \mathrm{~mm}$ layer. In the Sterkspruit soil form, an increase in the $S$-value with depth is observed whereas the opposite trend is observed in the Dundee soil form (Figure 4c).

The soluble Ca contents range from $0.9 \mathrm{mg} \mathrm{kg}^{-1}$ in the Dundee soil to $78.9 \mathrm{mg} \mathrm{kg}^{-1}$ in the Sterkspruit soil (Figure 5a). The magnitude of soluble Ca profiles is within the same order as that of the Clovelly, Dundee and Bonheim soil forms. This trend is remarkably different from the $S$-values calculated from the exchangeable cation concentrations. The magnitude of soluble Ca profiles in the Sterkspruit soil form is greater than that of the other soil forms. Soluble Mg profiles are very similar to that of Ca profiles; however, the concentrations are lower and the difference is smaller between the Sterkspruit and other soil forms (Figure 5b).

Soluble Na contents range from $1.1 \mathrm{mg} \mathrm{kg}^{-1}$ in surface horizons of the Clovelly to $6.1 \mathrm{mg} \mathrm{kg}^{-1}$ in the subsoil of the Sterkspruit form (Figure 5c). Structured soils (Sterkspruit and Bonheim) generally have higher soluble $\mathrm{Na}$ concentrations than the apedal soils. All soils show an increase in Na with depth, although this increase is variable in the Bonheim and Dundee soils.

\section{Hydraulic parameters}

The bulk density, water content at different suction levels and measured saturated hydraulic conductivity for the modal profiles indicate a large degree of variation in the physical properties (Table 2). The yellow-brown apedal B (ye) horizon of the Clovelly soil has the highest bulk density $\left(1.73 \mathrm{~g} \mathrm{~cm}^{-3}\right)$ with the lowest bulk density recorded in the soil/bedrock transition (on) horizon of the Bonheim soil $\left(1.32 \mathrm{~g} \mathrm{~cm}^{-3}\right)$. The high bulk density of the Clovelly soil translates to relatively low water content at saturation (low porosity) when compared to the higher clay content horizons. Water content decreases rapidly in the sandy soils, with $0.19 \mathrm{~mm} \mathrm{~mm}^{-1}$ and $0.20 \mathrm{~mm} \mathrm{~mm}^{-1}$ available at $800 \mathrm{~mm}$ of suction. The water holding capacity of the structured horizons is considerably higher. At $800 \mathrm{~mm}$ suction, the water content in the Sterkspruit soil is around $0.35 \mathrm{~mm} \cdot \mathrm{mm}^{-1}$ and ranges from 0.28 to 0.40 in the Bonheim soil.

Saturated hydraulic conductivities were very high in the Clovelly soil and exceeded $50 \mathrm{~mm} \mathrm{~h}^{-1}$ for all horizons (Table 2). The Sterkspruit soil form had the lowest conductivity that ranges between $3 \mathrm{~mm} \mathrm{~h}^{-1}$ and $5 \mathrm{~mm} \mathrm{~h}^{-1}$. In the Bonheim soil, the conductivity decreased steadily from the surface to the soil/ bedrock interface with 44,28 and $12 \mathrm{~mm} \mathrm{~h}^{-1}$ conductivity for the melanic, pedocutanic and unconsolidated horizons respectively (Table 2).

\section{Discussion}

\section{Hydropedological response based on soil morphology}

At the crest and midslope, the soil morphology of the sandy Clovelly and Mispah forms indicates that soil weathering of

TABLE 2: Physical measurements of three modal profiles.

\begin{tabular}{|c|c|c|c|c|c|c|c|c|c|c|c|c|c|}
\hline \multirow[t]{2}{*}{ Profile } & \multirow[t]{2}{*}{ Soil form } & \multirow[t]{2}{*}{ Horizon } & \multirow[t]{2}{*}{ Depth (mm) } & \multirow{2}{*}{$\frac{\text { Bulk density }}{\left(\text { g. } \mathrm{cm}^{-3} \text { ) }\right.}$} & \multicolumn{8}{|c|}{ Water contents $\left(\mathrm{mm} \cdot \mathrm{mm}^{-1}\right)$ at different suction levels $(\mathrm{mm})$} & \multirow{2}{*}{$\frac{K_{\mathrm{s}}}{\left(\mathrm{mm} \mathrm{h}^{-1}\right)}$} \\
\hline & & & & & 0 & 38 & 50 & 100 & 200 & 400 & 600 & 800 & \\
\hline \multirow[t]{2}{*}{1} & Clovelly & ot & 200 & 1.70 & 0.38 & 0.36 & 0.35 & 0.34 & 0.32 & 0.26 & 0.22 & 0.19 & 182 \\
\hline & & ye & 700 & 1.73 & 0.39 & 0.35 & 0.33 & 0.31 & 0.29 & 0.25 & 0.22 & 0.20 & 57 \\
\hline \multirow[t]{3}{*}{2} & Sterkspruit & ot & 100 & 1.62 & 0.40 & 0.39 & 0.38 & 0.37 & 0.36 & 0.35 & 0.34 & 0.33 & 3.1 \\
\hline & & pr1 & 300 & 1.55 & 0.44 & 0.42 & 0.41 & 0.40 & 0.39 & 0.38 & 0.37 & 0.36 & 5.5 \\
\hline & & pr2 & 600 & 1.62 & 0.42 & 0.39 & 0.38 & 0.37 & 0.36 & 0.35 & 0.34 & 0.33 & 3 \\
\hline \multirow[t]{3}{*}{3} & Bonheim & $\mathrm{ml}$ & 200 & 1.53 & 0.46 & 0.42 & 0.42 & 0.40 & 0.38 & 0.33 & 0.30 & 0.28 & 43.9 \\
\hline & & $\mathrm{vp}$ & 600 & 1.52 & 0.45 & 0.43 & 0.42 & 0.41 & 0.38 & 0.35 & 0.32 & 0.31 & 27.5 \\
\hline & & on & 800 & 1.32 & 0.52 & 0.50 & 0.49 & 0.48 & 0.46 & 0.44 & 0.42 & 0.40 & 12.3 \\
\hline
\end{tabular}

ot, orthic A; ye, yellow-brown apedal B; pr, prismacutanic B; pr1, prismacutanic 1; pr2, prismacutanic; ml, melanic A; vp, pedocutanic B; on, unspecified material with signs of wetness. 


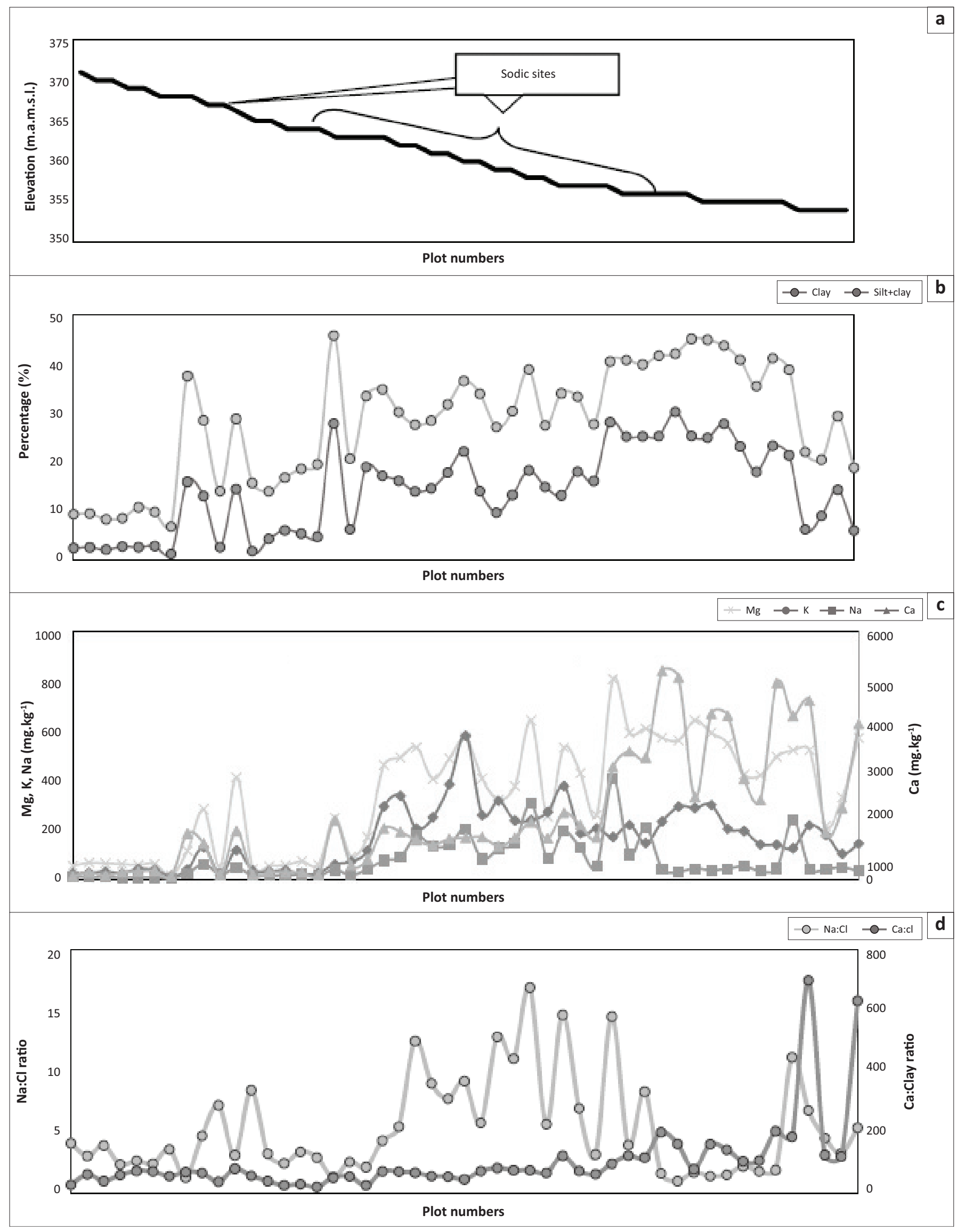

FIGURE 3: Profile of average physical and chemical properties along the catena. (a) Topography/elevation of the catena, (b) particle size distribution, (c) basic cations, (d) selected cation to clay ratios and (e) $\mathrm{pH}$ and exchangeable sodium percentage. 


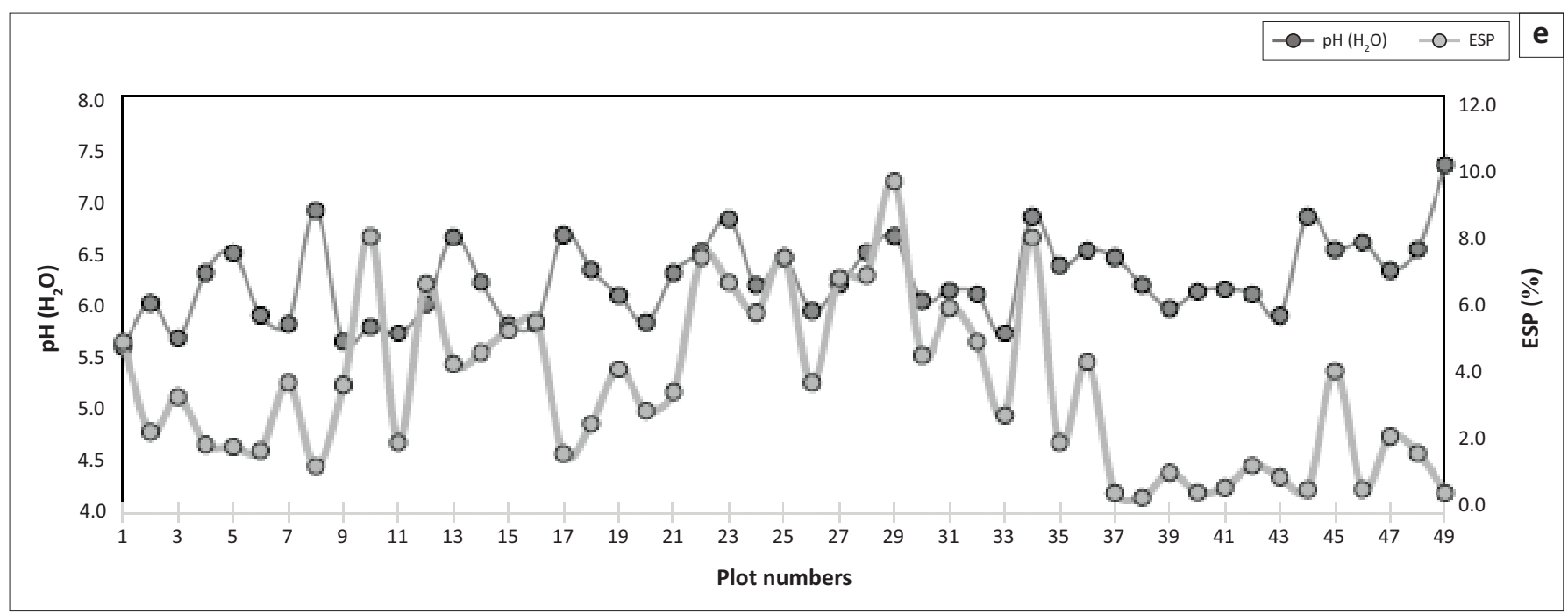

FIGURE 3 (Continues...): Profile of average physical and chemical properties along the catena. (a) Topography/elevation of the catena, (b) particle size distribution, (c) basic cations, (d) selected cation to clay ratios and (e) $\mathrm{pH}$ and exchangeable sodium percentage.

granitic parent material is the dominant soil-forming process. Horizonisation is visible as yellowing of the $\mathrm{B}$ horizon and slight darkening of the orthic horizon because of accumulation of organic matter. The low clay contents indicate that silicate clay, which is formed during weathering of the granite, is eluviated (Figures $3 \mathrm{~b}$ and $4 \mathrm{a}$ ). The yellow colour of the Clovelly soils is related to the presence of iron oxides, especially Goethite, which are stable and do not occur in soils saturated for significant periods (Schwertmann 1985). Hydrologically, it implies that a perched water table is not formed in these soils, and deep drainage into the saprolite and fracture rock is the dominant process.

The occurence of a bleached (grey colours as defined in SCWG 1991) B2 horizon in the Pinedene soil form (Table 1 and Figure 2) in the lower-midslope indicates redoximorphic process in the deep subsoil. Bleaching is dependent on reduction associated with energy supplied to microbes in the form of organic matter and prolonged saturation (Vepraskas, Huffman \& Kreiser 2006). In environments subjected to high evaporative demands, prolonged saturation requires that water is fed to the soil through a sustained flowpath of water. In this hillslope, this implies that flow at the soil/bedrock interface could occur in the saprolite horizon of the Clovelly soil or that the water which infiltrated into the fractured rock below the Clovelly and Mispah soils returns to the solum under the influence of gravitation to the Pinedene soil downslope. These indicators are supported by the occurrence of a Fernwood soil below the Pinedene soil. In simple terms, the bleached horizon at the soil/bedrock interface of the Pinedene soil becomes deeper downslope until the entire subsoil is bleached.

The lateral flowing water continues to accumulate until it reaches the prismatcutanic horizon in the Estcourt soil. Estcourt soils are known for the generation of lateral flow (Van Tol et al. 2013). The prismacutanic horizon acts as a clay plug and governs the lateral flowing water to return to the surface, forming a seepline. The grey colour of the E-horizon of the Estcourt soil further supports this lateral flowpath. The grey colour is the result of removal of iron oxide under reducing (saturated) conditions (Schwertmann 1985; Van Huyssteen et al. 2007). Topsoil erosion, high clay contents and the presence of prismacutanic horizons with strong structure signify that overland flow is the dominant hydrological flowpath in this part of the hillslope. Soil morphology indicates soil formation by clay enrichment due to either, or a combination of, physical (illuviation) or chemical (neoformation) processes (Owliaie, Abtahi \& Heck 2006).

The Bonheim and Milkwood soils of the lower-footslope indicate that weathering is more prominent than in the upper-footslope. Angular blocky structured pedocutanic horizons are in a more advanced stage of weathering than the primary prismatic and secondary angular blocky structures of the prismacutanic soils in the upper-footslopes. The dominant flowpath is still overland flow towards the valley bottom with limited vertical flow. This is expected because of the high clay contents and strong structure of the melanic and pedocutanic horizons. Dundee soils occurring in the valley bottom/riverbed are formed because of alluvial deposits from upstream. The coarse texture of the Dundee soils serves as an area of infiltration and recharge of overland flow from upslope positions as well as during streamflow episodes, that is, the stream is losing water to the groundwater.

The distribution of the soils in the catena indicates four distinctly different zones of soil formation related to different sets of hillslope flowpaths and storage mechanisms. Firstly, soils on the crest indicate soil formation by weathering of granitic parent material with a dominant vertical flowpath recharging the underlying fractured rock. Secondly, in the midslope position, soil morphology indicates subsoil saturation and associated reducing conditions. This results in gleysation and bleaching at the soil/bedrock interface because of removal of iron oxides. The dominant flowpaths are interflow at the soil/bedrock interface which returns to the surface to form a hillslope seep-line. Thirdly, on the footslope, soil morphology indicates soil degradation in the form of water erosion. Overland flow dominates these soils 
and leaching is subdominant. The strong prismatic structure of the soils of the upper-footslope is an indication that solonisation (accumulation of $\mathrm{Na}$ ) dominates. In the lowerfootslope, the weathering of the prismatic structure into angular blocky structure is because of slightly wetter moisture regimes. Lastly, in the valley bottom, recharge occurs in coarse materials that were deposited during flood events.

\section{Hydropedological response inferred from soil chemical trends}

The change in subsoil chemistry from the crest to the valley bottom is correlated to changes in soil types (Figures 2 and 3). Low concentrations of base cations and low $\mathrm{pH}$ in the apedal soils at the crest and midslope positions (plots 1 to 7 ) indicate that eluviation is a dominant process. The almost constant low $\mathrm{S}$-value (Figure $4 \mathrm{c}$ ) and soluble $\mathrm{Ca}, \mathrm{Mg}$ and $\mathrm{Na}$ cations (Figure 5) at different depths in the Clovelly soil support the deduction made from morphological properties, that is, the vertical flow through and out of these profiles is dominant. Bouwer et al. (2015) found similar trends in freely drained soils in the Weatherley research catchment, South Africa.

At plot 8, there was a marked increase in silt+clay contents and cations associated with the Sterkspruit soil form. The accumulation of cations, especially $\mathrm{Ca}$, suggests that leaching is limited. Significant increase in the $\mathrm{Ca}: \mathrm{Cl}$ ratio (Figure $3 \mathrm{~d}$ ) signifies the presence of 2:1 clay minerals formed by neoformation (Wilson 1999).

Very high soluble concentrations of $\mathrm{Ca}, \mathrm{Mg}$ and $\mathrm{Na}$ cations in the subsoil of plot 17 (Ss - Figure 5) suggest that a considerable amount of these cations accumulate in this 'clay plug'. The interpretation is that lateral flow occurs at the soil/bedrock interface from plot 11 to 15 , carrying dissolved cations which accumulate in the prismacutanic layer of the Sterkspruit soil form. This supports the morphological interpretation that plots 11 to 15 are interflow soils. Water presumably dams up behind the clay plug and, as water is lost to evapotranspiration (ET), cations accumulate in the soil resulting in an increase in the $\mathrm{pH}$.

The change from apedal soils to structured soils (Figure 2) is marked by an increase in clay contents (Figure 3b) as well as an increase in ESP (Figure 3e). This marks the change from acidic to sodic soils. There is a change from leaching environment in the apedal soils to an accumulation in the structured soils, as clearly shown by the increase of base cations at the sodic site (note the increase in $\mathrm{Na}: \mathrm{Cl}$ ratios as shown in Figure 3d).

Plot 36 marks the lower boundary of the sodic site; the soils change from Sterkspruit to Bonheim forms (Figures 2 and $3 a)$. The relatively high $\mathrm{pH}$ and $S$-value of the surface horizon (50 mm) of the Bonheim (Bo) soil, compared to the $150 \mathrm{~mm}$ layer (Figure 4), suggest that surface accumulations of cations are dominant. This indicates that overland flow water, rich in dissolved cations, will accumulate at the break of slope. Below plot 36, prismacutanic horizons are degrading into pedocutanic horizons (Figure 2). Although the absolute concentrations of exchangeable cations are still relatively high, the cation to clay ratio decreases notably (Figure 3d). This implies that vertical drainage becomes slightly more important than in the sodic soils. The combination of more gentle slopes and blocky structures (compared to prismatic) could be attributed to enhanced infiltration (Kutílek 2004; Leeds-Harrison et al. 2007).

The variation in concentrations in plots $47-49$ is associated with the deposition of different materials in the Dundee soil on the flood banks of the streams (Figure 3). Vertical variation in chemical properties is clearly depicted in Figures 4 and 5, which demonstrate the variation in deposited materials. The decreasing $S$-value with depth suggests that leaching is dominant in this profile, also supported by the morphological interpretation of soil properties.

\section{Hydraulic property support for the interpretation of morphology and pedochemistry}

The water contents at different suction levels and saturated hydraulic conductivity of the Clovelly soil support the

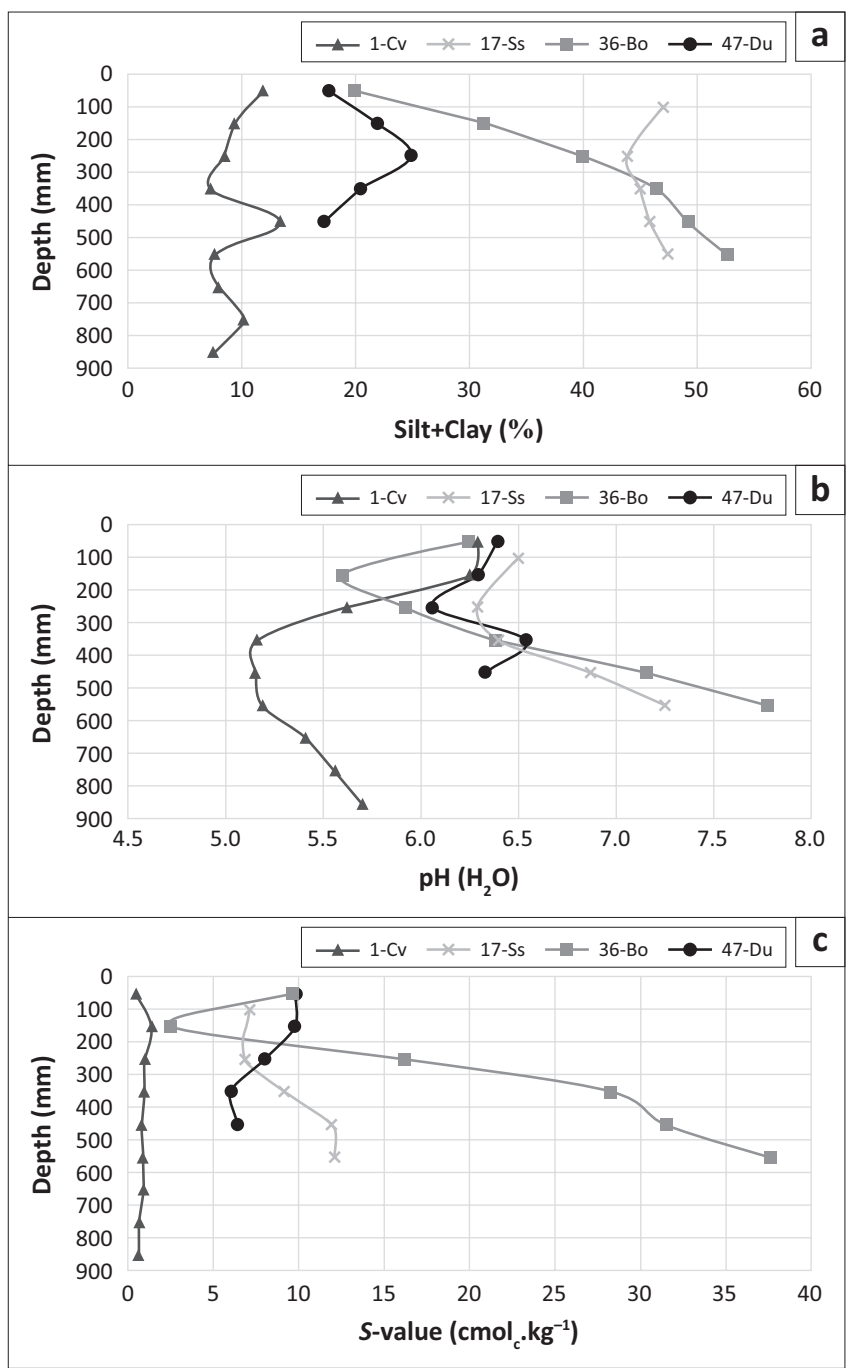

Cv, Clovelly; Ss, Sterkspruit; Bo, Bonheim; Du, Dundee.

FIGURE 4: Vertical distribution of selected properties in modal profiles. (a) Silt+clay contents, (b) $\mathrm{pH}$ profiles and (c) $\mathrm{S}$-value. 


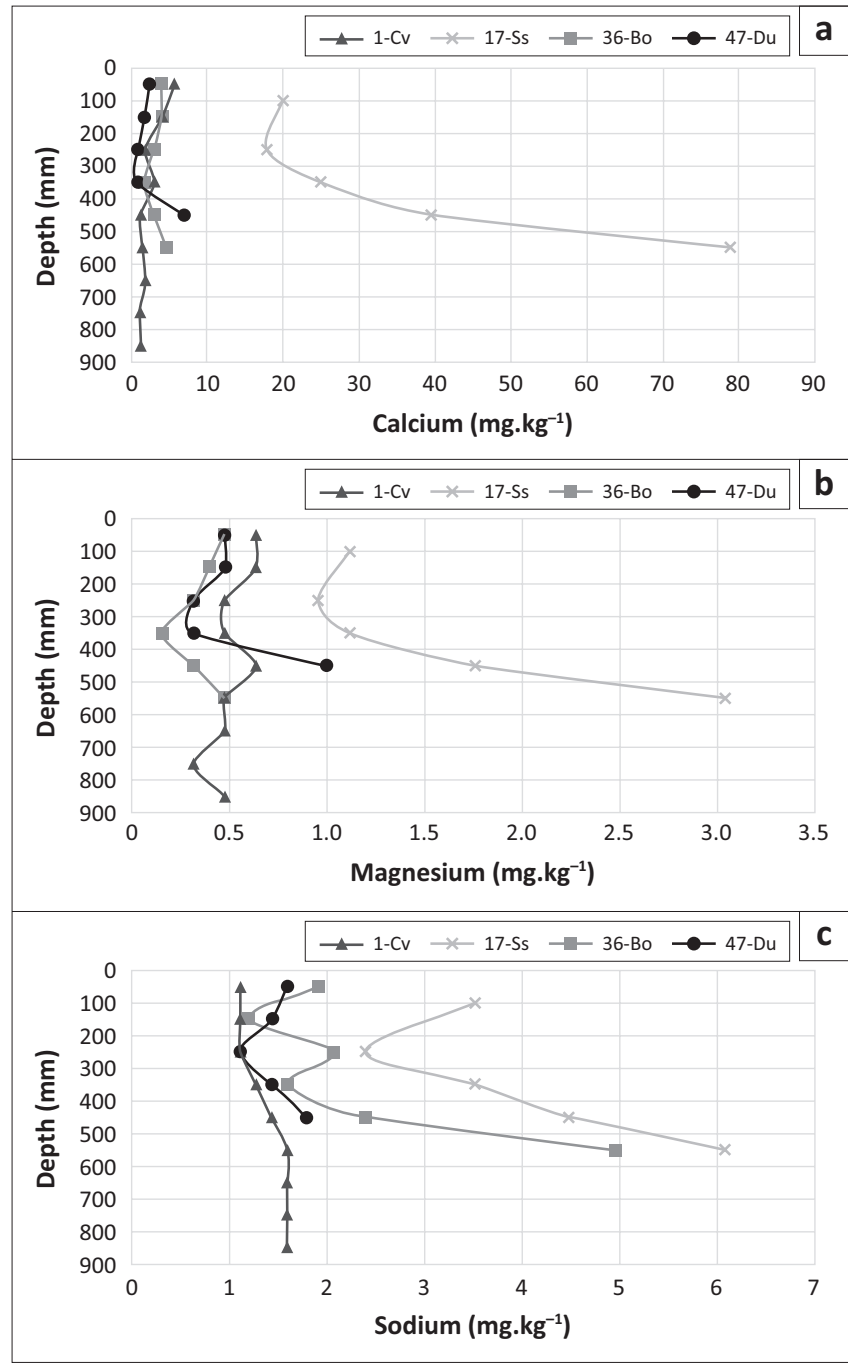

FIGURE 5: Soluble cation modal profiles: (a) calcium (Ca), (b) magnesium (Mg) and $(\mathrm{c})$ sodium $(\mathrm{Na})$.

morphological and chemical deductions that apedal horizons are a fast flowpath (Table 2). The high $K_{\mathrm{s}}$ value in the orthic horizon suggests that soluble cations could easily be leached from the horizon. The steep decrease in water retention suggests that macroporosity in this horizon is high (Leeds-Harrison et. al. 2007). This implies that conditions for complete saturation are hardly met because of the fast drainage of macropores.

The water retention data and $K_{\mathrm{s}}$ of the Sterkspruit soil are in accordance with morphological and chemical interpretations that water movement is very slow in the prismacutanic horizon (Table 2). Dispersion of clays, associated with the high Na content, could clog soil pores resulting in the low conductivity. The gradual decrease in water retention of the Sterkspruit indicates that macroporosity is relatively low under saturated conditions, that is, most of the water is held in the soil matrix.

The water retention data and $K_{\mathrm{s}}$ of the Bonheim soil support the morphological and chemical interpretations that water movement is faster than that observed in the Sterkspruit soil (Table 2). The decrease in water content with an accompanying increase in pressure is considerately less than in the Pinedene soil. The structure of the pedocutanic horizon promotes the presence of more macropores, as is evident by the water retention data. In spite of the greater number of macropores, compared to the Sterkspruit, the soil is dominated by smaller pores.

\section{Conceptual hydropedological response model from morphology, chemistry and hydraulic measurements}

The conceptual hydrological response model of this hillslope is presented in Figure 6. This model was constructed from the interpretation of soil morphological properties and then refined and improved using measurements and interpretations of soil chemical and physical properties. The numbered arrows in Figure 6 reflect different dominant and subdominant hydrological flowpaths/processes as discussed below:

1. Infiltration and vertical flow are dominant in the Clovelly soils of the crest position. This is supported by the apedal structure, absence of grey colours, sandy texture, low $\mathrm{pH}$, low base cation concentrations and high $K_{\mathrm{s}}$ values. In the valley bottom, infiltration is also dominant in the streambeds and through coarse alluvial material. Reinfiltration of overland flowing water is likely to occur in the gentle slopes of this terrain position.

2. In this semi-arid environment, evapotranspiration is also dominant (see, for example, Van Tol et al. 2015). A great portion of infiltrated water is likely to evaporate or transpire back into the atmosphere. Evapotranspiration is likely to be high in the valley bottom-associated riparian vegetation.

3. The majority of the hillslope is covered by soils with relatively high clay contents and low hydraulic conductivity. These soils are also characterised by a high base status and $\mathrm{pH}$, which is associated with limited leaching. Overland flow is considered to be the dominant hydrological process. Erosion of surface horizons is additional confirmation that overland flow dominates in the upper- and lower-footslope positions.

4. The presence of hydromorphic B2 horizons suggests that saturated conditions exist during wet periods. Because these hydromorphic signatures become more prominent downslope (up to the start of the sodic site), this is an indication that lateral flow occurs here. This is supported by an increase in soluble base cations in a downslope direction.

5. When this lateral flowing water in (4) reaches the clayenriched Sterkspruit soils, the water accumulates until the storage capacity of the soils is exceeded and exfiltration in the form of a seepage face takes place. This return flowpath contributes to overland flow.

6. Infiltration into fractures of the granitic parent material (recharge) is possible, although considered a subdominant process in the greater part of this hillslope. On the crest and in the valley bottom, significant recharge could take place during extreme rainfall events.

\section{Conclusion}

Terrain morphology is a common representative of homogeneous ecological units in pristine granite landscapes 


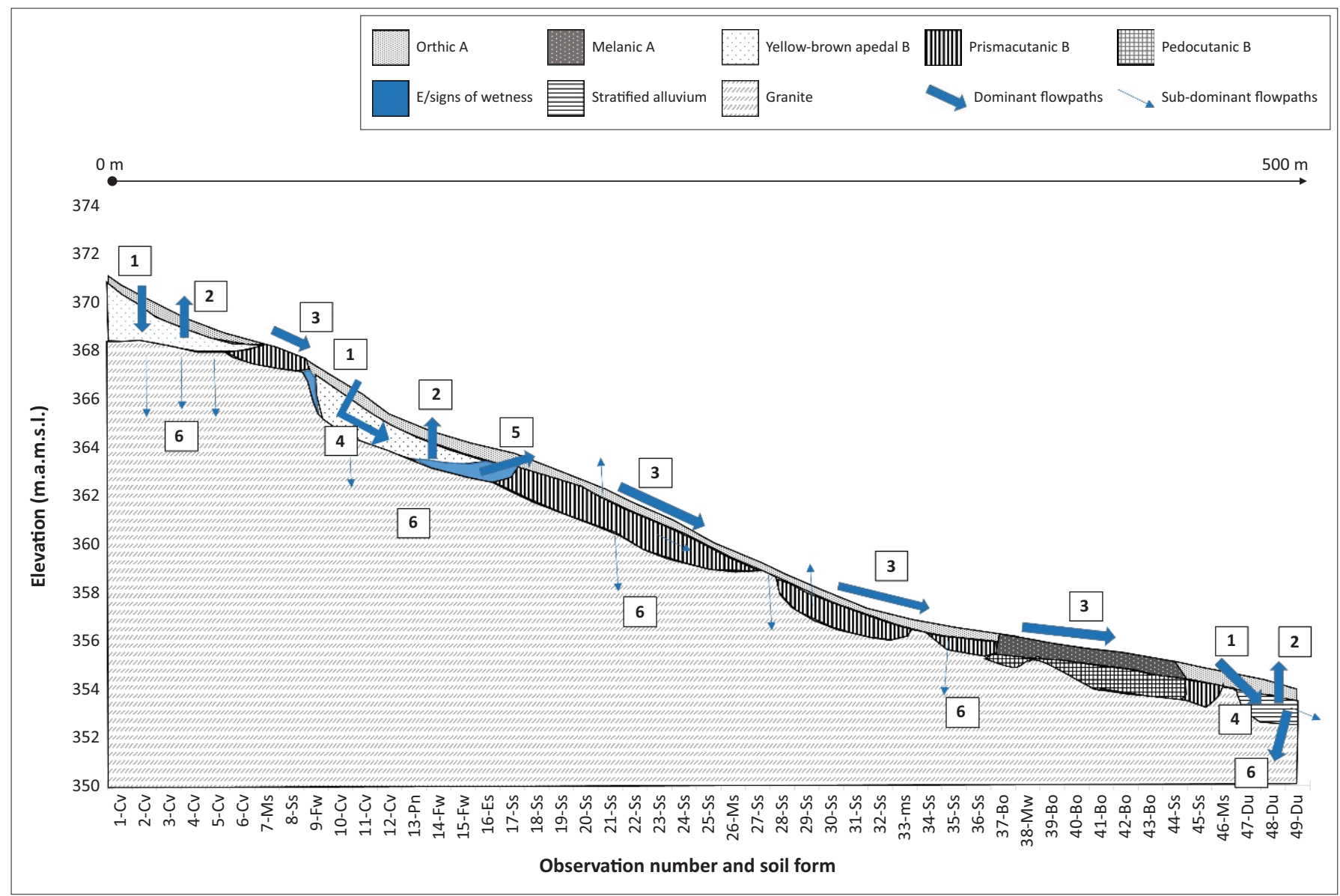

Cv, Clovelly; Ms, Mispah; Ss, Sterkspruit; Fw, Fernwoord; Pn, Pinedene; Es, Estcourt; Bo, Bonheim; Mw, Milkwood; Du, Dundee.

FIGURE 6: Conceptual hydrological response model of a third-order stream in the Kruger National Park. Vertical axis exaggerated for display purposes.

of the Kruger National Park. This catenal effect is an interaction between water, topography and geology as primary components and relates to a hydropedological composition. This composition is both an indication of partitioning and a control factor of movement and storage of water in the catena.

Soil morphology is strongly associated with the hydrological response. The degree to which chemical properties are in sync with current pedological process emphasises the fact that the soils are mature and chemistry and morphology are useful indicators of hydrological response. Chemistry must be interpreted from several observations and with depth, as it responds to the environmental impact within the phase of pedogenesis. Chemical indicators of leaching were used as indicators for flowpaths, although the prediction of flow direction depends on slope and indicators of return flow. The accumulation of cations was an indication of a slow flowpath. Low subsoil $\mathrm{pH}$, and therefore low cation concentration, was used as an indicator of ferrolysis because of periodic saturation. The accumulation of cations in apedal horizons improved morphological interpretation, as the horizons did not respond as fast flowpaths but rather as a storage mechanism induced by the poor drainage of the underlying rock. The chemical properties confirmed the degrading of Sterkspruit to Bonheim soil. The melanic and pedocutanic horizons had chemical trends similar to orthic and prismacutanic horizons, except in lower concentrations. The $\mathrm{C}$ horizon of the Bonheim soil has similar chemical properties as those of the prismacutanic horizons.

Pedon scale hydropedology contributed to the understanding of the physical catena and predicted a strong correlation with the biological catena. The use of morphology, chemistry and physics resulted in improving the conceptual understanding of a conceptual model and soil types. Thus, the technique to use soil chemical properties to identify flowpaths in soils has improved the conceptual hydrological models compared to those where only soil morphology was used.

\section{Acknowledgements Competing interests}

The authors declare that they have no financial or personal relationships that may have inappropriately influenced them in writing this article.

\section{Authors' contributions}

D.B. and P.A.L. led the research design and conducted fieldwork. D.B. was responsible for lab and data analysis. J.v.T. and D.B. were responsible for data interpretation and the write-up of the article. 


\section{Funding information}

The authors are grateful to the University of the Free State for funding this multidisciplinary research and the Water Research Commission (WRC) of South Africa under project number K5/2051.

\section{Data availability}

Data are available upon request to the corresponding author. Data from all research done within Kruger National Park is placed within the SANParks repository (not for free, open access).

\section{Disclaimer}

The views and opinions expressed in this article are those of the authors and do not necessarily reflect the official policy or position of any affiliated agency of the authors.

\section{References}

Bouwer, D., Le Roux, P.A., Van Tol, J.J. \& Van Huyssteen, C.W., 2015, 'Using ancient and recent soil properties to design a conceptual hydrological response model', Geoderma 241-242, 1-11. https://doi.org/10.1016/j.geoderma.2014.10.002

Bouwer, H. \& Rice, R.C., 1976, 'A slug test for determining hydraulic conductivity of unconfined aquifers with completely or partially penetrating wells', Water Resources Research 12(3), 423-428. https://doi.org/10.1029/WR012i003p00423

Dippenaar, M.A. \& Van Rooy, J.L., 2014, 'Review of engineering, hydrogeological and vadose zone hydrological aspects of the Lanseria gneiss, Goudplaats-Hout rive gneiss and Nelspruit suite granite (South Africa)', Journal of African Earth Sciences 91, 12-31. https://doi.org/10.1016/j.jafrearsci.2013.11.019

Dirksen, C., 1999, Soil physics measurements, Catena Verlag, Reiskirchen.

Essington, M.E., 2004, Soil and water chemistry: An integrative approach, CRC Press, New York, NY.

International Union of Soil Sciences Working Group World Reference Base (WRB) 2015, World reference base for soil resources 2014: International soil classification system for naming soils and creating legends for soil maps, World classification system for naming soils and creating legends for soil maps, World soil resources repc

Kuenene B.T., Le Roux P.A.L., Van Huyssteen C.W. \& Hensley M., 2013, 'Selected soil properties as indicators of soil water regime in the Cathedral peak VI catchment of KwaZulu-Natal, South Africa', South African Journal of Plant \& Soil 30(1), 1-6. KwaZulu-Natal, South Africa', South African Journ
https://doi.org/10.1080/02571862.2013.767387

Kutílek, M., 2004, 'Soil hydraulic properties as related to soil structure', Soil Tillage Research 79(2), 175-184. https://doi.org/10.1016/j.still.2004.07.006

Kutílek, M. \& Nielsen, D.R., 2007, 'Interdisciplinarity of hydropedology', Geoderma 138(3-4), 252-260. https://doi.org/10.1016/j.geoderma.2006.11.015

Leeds-Harrison, P.B., Shipway, C.J.P., Jarvus, N.J. \& Youngs, E.G., 2007, 'The influence of soil macroporosity on water retention, transmission and drainage in a clay soil', Soil Use and Management 2(2), 47-50. https://doi.org/10.1111/j.1475-2743.1986. tb00678.x

Lin, H.S., 2003, 'Hydropedology: Bridging disciplines, scales, and data', Vadose Zone Journal 2(1), 1-11. https://doi.org/10.2136/vzj2003.1000

Lin, H.S., 2010, 'Earth's critical zone and hydropedology: Concepts, characteristics, and advances', Hydrology and Earth System Sciences 14(1), 25-45. https://doi. org/10.5194/hess-14-25-2010

Lin, H.S., Bouma, J., Pachepsky, Y., Western, A.W., Thompson, J., Van Genuchten, R. et al., 2006a, 'Hydropedology: Synergistic integration of pedology and hydrology', Water Resources Research 42(5), 1-13. https://doi.org/10.1029/2005WR004085

Lin, H.S., Kogelmann, W., Walker, C. \& Bruns, M.A., 2006b, 'Soil moisture patterns in a forested catchment: A hydropedological perspective', Geoderma 131(3-4), 345-368. https://doi.org/10.1016/j.geoderma.2005.03.013
Lin, H.S., Wheeler, D., Bell, J.C. \& Wilding, L.P., 2005, 'Assessment of soil spatial variability at multiple scales', Ecological Modelling 182(3-4), 271-290. https:// doi.org/10.1016/j.ecolmodel.2004.04.006

MacEwan, R.J., 1997, 'Soil quality indicators: Pedological aspects', in E.G. Gregorich \& M.R. Carter (eds.), Soil quality for crop production and ecosystem health, pp. 143-166, Elsevier, New York, NY.

MacEwan, R.J. \& Fitzpatrick, R.W., 1996, 'The pedological context for assessment of soil quality', in R.J. MacEwan \& M.R. Carter (eds.), Soil quality is in the hands of the land manager. Proceedings of an international symposium on advances in soil quality for land management: Science, practice and policy, pp. 10-16, University of Ballarat, Ballarat.

Mamera, M. \& Van Tol, J.J., 2018, 'Application of hydropedological information to conceptualise pollution migration from dry sanitation systems in the Ntabelanga area, South Africa', Air, Soil and Water Research 11, 1-12. https://doi.org/ $10.1177 / 1178622118795485$

Owliaie, H.R., Abtahi, A. \& Heck, R.J., 2006, 'Pedogenesis and clay mineralogical investigation of soils formed on gypsiferous and calcareous materials, on transect, south-western Iran', Geoderma 134(1-2), 62-81. https://doi.org/ 10.1016/j.geoderma.2005.08.015

Riddell, E.S., Lorentz, S.A. \& Kotze, D.C., 2012, 'The hydrodynamic response of a semiarid headwater wetland to technical rehabilitation interventions', Water SA 38(1), 55-66. https://doi.org/10.4314/wsa.v38i1.8

Riddell, E.S., Nel, J., Fundisi, D., Jumbi, F., Van Niekerk, A. \& Lorentz, S., 2014, Ephemeral hydrological processes in savannas, Water Research Commission report no. TT619/14, Water Research Commission, Pretoria.

Robb, L.J., Brandl, G., Anhaeusser, C.R. \& Poujol, M., 2006, 'Archaean granitoid intrusions', in M.R. Johnson, C.R. Annhaeusser \& R.J. Thomas (eds.), The geology of South Africa, pp. 57-94, Geological Society of South Africa, Johannesburg.

Schwertmann, U., 1985, 'The effect of pedogenic environments on iron oxide minerals', Advances in Soil Science 1, 171-200. https://doi.org/10.1007/978-14612-5046-3_5

Smit, I.P.J., Riddell, E.S., Cullum, C. \& Petersen, R., 2013. 'Kruger National Park research supersites: Establishing long-term research sites for cross-disciplinary, multiscaled learning', Koedoe 55(1), Art. \#1107, 7 pages. https://doi.org/10.4102/koedoe. v55i1.1107

Soil Classification Working Group (SCWG), 1991, Soil classification: A taxonomic system for South Africa, Department of Agricultural Development, Pretoria.

The Non-Affiliated Soil Analysis Work Committee, 1990, Handbook of standard soil testing methods for advisory purposes, Soil Science Society of South Africa, Bloemfontein.

Van Huyssteen C.W., Le Roux P.A.L., Hensley M. \& Zere T.B., 2007, 'Duration of water saturation in selected soils of Weatherley, South Africa', South African Journal of Plant \& Soil 24(3), 152-160. https://doi.org/10.1080/02571862.2007.10634799

Van Tol, J.J., Hensley, M. \& Le Roux, P.A., 2013, 'Pedological criteria for estimating the importance of subsurface lateral flow in E horizons in South African soils', Water importance of subsurface lateral flow in E horizons in
SA 39(1), 47-56. https://doi.org/10.4314/wsa.v39i1.7

Van Tol, J.J. \& Le Roux, P.A.L., 2019, 'Hydropedological grouping of South African soil forms', South African Journal of Plant and Soil. 36(3), 233-235. https://doi.org/10. 1080/02571862.2018.1537012.

Van Tol, J.J., Le Roux, P.A., Lorentz, S.A. \& Hensley, M., 2010, 'Soil as indicator of hillslope hydrological behaviour in the Weatherley catchment, Eastern Cape, South Africa', Water SA 36(5), 513-520. https://doi.org/10.4314/wsa.v36i5.61985

Van Tol, J.J. \& Lorentz, S.A., 2018, 'Hydropedological interpretation of soil distribution patterns to characterise groundwater/surface-water interactions', Vadose Zone Journal 17(1), 1-13. https://doi.org/10.2136/vzj2017.05.0097

Van Tol, J.J., Lorentz, S.A., Van Zijl, G.M. \& Le Roux, P.A.L., 2018, 'The contribution of hydropedological assessments to the availability and sustainable water, for all (SDG\#6)', in R. Lal, R. Horn \& T. Kosaki (eds.), Soil and sustainable development goals, pp. 102-117, Catena-Schweizerbart, Stuttgart.

Van Tol, J.J., Van Zijl, G.M., Riddell, E.S. \& Fundisi, D., 2015, 'Application of hydropedological insights in hydrological modelling of the Stevenson Hamilton Research Supersite, Kruger National Park, South Africa', WaterSA 41(4), 525-533. https://doi.org/10.4314/wsa.v41i4.12

Van Zijl, G.M., Van Tol, J.J. \& Riddell, E.S., 2016, 'Digital mapping for hydrological modelling', in G. Zhang, D. Brus, F. Liu, X. Song \& P. Lagacherie (eds.), Digital soil mapping across paradigms, scales and boundaries, pp. 115-129, Springer, Singapore.

Vepraskas, M., Huffman, R.L. \& Kreiser, G.S., 2006, 'Hydrologic models for altered landscapes', Geoderma 131(3-4), 287-298. https://doi.org/10.1016/j.geoderma. landscapes', Geo
2005.03.010

Wilson, M.J., 1999, 'The origin and formation of clay minerals in soils: Past, present and future perspectives', Clay Minerals 34(1), 7-25. https://doi.org/10.1180/ 000985599545957 